\title{
Analysis of drinking water quality from the standpoint of health risks
}

\author{
Valentina Nikiforova $^{1, *}$, and Elena Vidishcheva $^{1}$ \\ ${ }^{1}$ Bratsk State University, 665709 Bratsk, Russia
}

\begin{abstract}
The paper presents a hygienic quality assessment of water from sources in the Irkutsk Region (Russia) used for public drinking water supply. The aim of the study is to assess health risks to the population of Bratsk and the Bratsk District, which is associated with the exposure to chemicals coming with drinking water from the public water supply system. Risk of occurrence and development of non-carcinogenic effects is assessed for separate age groups using a special method. Based on the risk assessment methodology, non-carcinogenic risks for children and adults are described in quantitative terms. The total health risk of the test groups associated with the oral intake of chemicals with drinking water is estimated as negligible and, therefore, does not need to be reduced through additional measures. Lead and fluoride contents in drinking water are the major contributors to the risk level $(59.5-68.4 \%)$. There is a risk of developing blood disorders and cardiovascular diseases in children of Bratsk $(\mathrm{HI}=1.19)$, as well as bone tissue and teeth disorders in children of Bikey village, Bratsk District $(\mathrm{HI}=1.10)$.
\end{abstract}

\section{Introduction}

Water is one of essential elements that are vital to every living creature on the Earth. With the development of new technologies, the need for water is growing day by day. The volume of world's water resources is estimated to be 1.3 billion $\mathrm{km}^{3}$, but strategically important fresh drinking water makes up only 2 to $2.6 \%$ [1].

South America and Asia have the largest reserves of available fresh water on the planet. Twenty-nine countries grouped together in terms of economy have a fifth of the available water resources. The post-Soviet states account for more than $20 \%$ of world's water resources. The rest of water resources are found in the Middle East and North Africa. It should be noted that India, China, the USA, Pakistan, Japan, Thailand, Indonesia, Bangladesh, Mexico and Russia demonstrate the highest consumption levels [2-4]. There is acute shortage of water in China, India and the USA. Currently, there are more than 260 international river basins shared by 145 nations. Such rivers as the Nile, Danube, Tigris and Euphrates, Ganges and Brahmaputra provide sufficient water to all consumers [5].

The CIS states have the largest water resources in the world and rank second (after Brazil) in terms of average annual river runoff. Moreover, the CIS states have significant potential groundwater reserves. However, these resources are distributed across CIS

\footnotetext{
*Corresponding author: nikiforovabr@mail.ru
} 
countries extremely unevenly due to various geographic, climatic, geological and hydrogeological conditions of regions.

The main sources of drinking water supply are river runoff, surface water and groundwater, the quality of which is estimated by researchers as unsatisfactory [5-7]. The major rivers of Russia (the Volga, Don, Kuban, Ob, Yenisei, Lena and Pechora), are rated as "heavily polluted", while water in the Neva, Tom, Oka and Ural rivers is unsuitable for drinking and domestic purposes. Due to pollution, water taken from such rivers as the Volga, Dnieper, Don, Kuban, Northern Dvina, Pechora, Ob, Yenisei, Lena, Kama, Amur and many lakes, needs to be specially treated.

Regions with the worst quality of drinking water include the republics of Dagestan, Ingushetia, Kalmykia, Karachay-Cherkessia, Karelia and Tatarstan, Altai Krai and Primorsky Krai, Arkhangelsk, Ivanovo, Kirov, Kostroma, Ryazan, Smolensk and Ulyanovsk regions. In the context of ever deteriorating water quality in sources, the available water treatment techniques cannot ensure the treatment of drinking water to the required level of purity.

In some regions of the world, including Russia, people have to use the water that does not meet the applicable standards. For example, in some water supply sources of the Orenburg Region, cadmium levels may reach $0.007 \mathrm{mg} / \mathrm{L}$, lead $-0.04 \mathrm{mg} / \mathrm{L}$, arsenic $0.023 \mathrm{mg} / \mathrm{L}$ [7]. Uganda uses groundwater with an iron content of 0.3 to $4.9 \mathrm{mg} / \mathrm{L}$, manganese - up to $2.0 \mathrm{mg} / \mathrm{L}$, arsenic $-0.005-0.009 \mathrm{mg} / \mathrm{L}$, nickel - up to $0.12 \mathrm{mg} / \mathrm{L}$, lead up to $0.011 \mathrm{mg} / \mathrm{L}$, cadmium - up to $0.013 \mathrm{mg} / \mathrm{L}$ [8]. In a mining region of Bangladesh, high concentrations of arsenic (from 0.01 to $0.049 \mathrm{mg} / \mathrm{L}$ ) were found in groundwater [9].

Thus, the problem of water quality is the focus of attention for the world community, legislative and executive bodies in all civilized countries and regions, which is associated with growing water consumption, qualitative changes in water sources that are often exposed to uncontrolled anthropogenic impact, and inadequate water treatment methods [10].

One of the most important tasks in the field of sanitary and epidemiological public welfare in the Russian Federation is to provide the population with high-quality drinking water that is epidemiologically safe and harmless in terms of chemical composition [11, 12]. Quality of drinking water supplied from public sources is one of the most important environmental factors that affect public health in the country, including the region under study.

To date, the development of epidemiological risk to public health have been studied with regard to drinking water treatment methods, the sanitary and technical condition of distribution networks, and the possibility of restoring microorganisms during transportation of water [13]. Transformation of chemical substances caused by various physical and chemical methods of water treatment, and the possibility of changing the chemical composition of water and its organoleptic properties in the distribution network have been studied as well [14]. However, the water factor has its own specific effects on human health, as evidenced by a number of studies in which drinking water quality and public health risks have been analyzed from a hygienic perspective [15-17].

In order to preserve the health of the nation, while creating favorable conditions for business entities, it is necessary to use new approaches to the management of sanitary and epidemiological supervisory bodies. One of these approaches is a risk-based model of surveillance in the field of sanitary and epidemiological public welfare as related to drinking water of proper quality [18]. In a specific sanitary situation, the relevant and effective tool is to assess the public health risk arising from the water factor by calculating doses to which certain population groups are exposed [19].

The aim of this study is to assess the public health risk associated with the exposure to chemicals coming with drinking water from the public drinking water supply system (based 
on cities and settlements of the Irkutsk Region). The scientific novelty is associated with comparative compositional analysis of drinking water taken from quality control points. Low carcinogenic risk of drinking water for children of Bratsk and low non-carcinogenic risk for children of the Bikey village (Bratsk District) were identified.

\section{Materials and Methods}

When selecting a test object, we assessed all controlled underground sources of the Irkutsk region located in rural (28 districts) and urban municipalities (9 cities). Bratsk and other settlements of the Bratsk District were selected as test objects.

To accomplish this task, we undertook a retrospective comprehensive assessment and analysis of laboratory data included in a database of the regional social and hygienic monitoring system in the Bratsk Branch of the Irkutsk Region Center of Hygiene and Epidemiology (Federal Budgetary Healthcare Institution) for the period from 2000 to 2015.

The quality of drinking water from underground sources was assessed for compliance with SanPiN 2.1.4.1074-01 Drinking Water. Hygienic Requirements for Water Quality of Public Drinking Water Supply Systems. Quality Control. Hygienic Requirements for Safety of Hot Water Supply Systems [20]. The quantitative analysis of water pollution was carried out in accordance with GN 2.2.5.1315-03 Maximum Allowable Concentrations (MACs) of Chemicals in Water of Water Facilities Used for Household and Domestic Purposes [21].

The risk was assessed using the classical procedure [22] on the basis of data from systematic monitoring of water quality performed by Teplovodokanal (municipal water supply enterprise) of Bratsk municipality under the production monitoring program, and on the basis of laboratory data provided by the Bratsk Branch of the Irkutsk Region Center of Hygiene and Epidemiology as part of social and hygienic monitoring efforts.

The research consists of the following stages: health hazard identification, determination of dose-response relationships, exposure assessment, and risk characterization. Subject to the aim of the study, we considered an exposure scenario that implies the oral intake of harmful substances with water. Oral non-carcinogenic effects were assessed in terms of hazard quotients and indices. Hazard indicators of the chemicals identified through monitoring were estimated on the basis of reference levels for chronic exposure to chemicals. At the same time, we identified critical organs/systems and effects that corresponded to the established reference doses.

The risk assessment was carried out at four water quality control points of the public water supply system, which receives water from water intakes providing the population of Bratsk with water for domestic and drinking purposes. The risk indicators estimated on the basis of drinking water quality data from the control points were extended to people who used this water for drinking purposes. When estimating the non-carcinogenic risk, we used exposures of 12 chemicals, while calculating average daily doses of toxic agents separately for adults and children.

\section{Results and Discussion}

238 samples (data from the regional social and hygienic monitoring system) taken from public drinking water supply systems in 41 municipalities of the Irkutsk Region were tested. In terms of chemical composition (iron, manganese, nitrates), organoleptic indicators (color, turbidity) and total hardness, $15.5 \%$ of the tested samples did not meet the standard. Unsatisfactory samples were recorded in Bokhansky (100\% of samples), Alarsky (50\%), Ekhirit-Bulagatsky (42.9\%), Chunsky (66.7\%), Kachugsky (66.7\%) districts, 
Bodaybo town and district (42.9\%), Irkutsky (35\%), Usolsky, Ust-Ilimsky and Bratsk districts.

In terms of microbiological safety, $3.3 \%$ of drinking water samples water quality did not meet hygienic requirements (including samples from Bokhansky (Buret village), Tulunsky (Badar village), Irkutsky (Revyakin village, Mamony village, Sosnovy Bor village, Nikolsk village) districts, as well as in Irkutsk city and Shelekhov town.

Monitoring of drinking water quality in non-public water supply in the Irkutsk Region was carried out in 33 municipalities. The tested samples do not comply with hygienic standards in terms of sanitary and chemical indicators (Fig. 1), including chemical composition (iron, manganese, nitrates) and total hardness, as well as in terms of organoleptic indicators (color, turbidity).

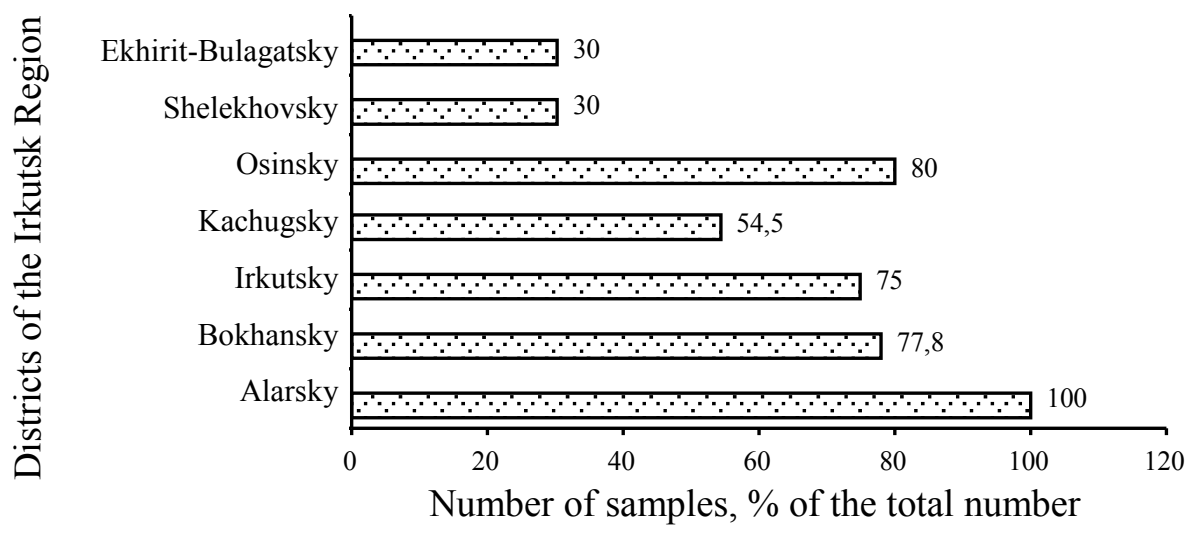

Fig. 1. The number of samples taken in the Irkutsk Region that do not comply with standard sanitary and chemical indicators.

In terms of sanitary and chemical indicators, from 30 to $100 \%$ of the samples taken in the districts of the Irkutsk Region under study do not meet the standard. In terms of microbiological safety, $3.7 \%$ of water samples are not compliant.

Thus, according to data of the regional social and hygienic monitoring system, there is a high proportion of water test samples from some areas of the Irkutsk Region that do not meet hygienic standards in terms of sanitary and hygienic indicators.

The health risk assessment gives more reliable information about the exposure of the population to the toxicological hazard of drinking water. The chemical composition of drinking water from the Bratsk public drinking water supply system is presented in Table 1.

The chemical analysis of drinking water at all control points shows that the average concentrations do not exceed the limits of the standards, but the maximum levels are often above the MACs. 
Table 1. Chemical Composition of Drinking Water from the Bratsk Public Drinking Water Supply System.

\begin{tabular}{|c|c|c|c|c|c|c|c|c|}
\hline \multirow{2}{*}{$\begin{array}{c}\text { Water quality control } \\
\text { points }\end{array}$} & \multicolumn{8}{|c|}{ Chemical composition } \\
\hline & \multicolumn{2}{|c|}{ Bratsk (city) } & \multicolumn{2}{|c|}{ Padun (village) } & \multicolumn{2}{|c|}{ Bikey (village) } & \multicolumn{2}{|c|}{ Zayarsk (village) } \\
\hline Substance & 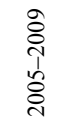 & 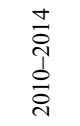 & 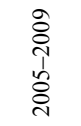 & 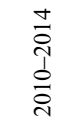 & 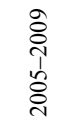 & 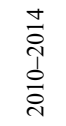 & 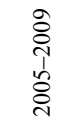 & 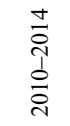 \\
\hline $\mathrm{NO}_{3}^{-}, \mathrm{mg} / \mathrm{dm}^{3}$ & 2.41 & 2.52 & 0.54 & 0.87 & 0.71 & 2.08 & 6.96 & 6.73 \\
\hline $\mathrm{Fe}^{3+}, \mathrm{mg} / \mathrm{dm}^{3}$ & 0.04 & 0.02 & 0.03 & 0.02 & 0.05 & 0.04 & 0.02 & 0.05 \\
\hline $\mathrm{F}^{-}, \mathrm{mg} / \mathrm{dm}^{3}$ & 0.48 & 0.48 & 0.43 & 0.41 & 0.54 & 0.53 & 0.52 & 0.54 \\
\hline $\mathrm{Mn}^{2+}, \mathrm{mg} / \mathrm{dm}^{3}$ & 0.003 & 0 & 0.005 & 0.009 & 0.001 & 0.006 & 0.003 & 0.005 \\
\hline $\mathrm{As}^{2+}, \mathrm{mg} / \mathrm{dm}^{3}$ & 0 & 0.002 & 0 & 0.002 & 0 & 0.001 & 0.0001 & 0.0001 \\
\hline $\mathrm{B}^{-}, \mathrm{mg} / \mathrm{dm}^{3}$ & 0.13 & 0.15 & 0.05 & 0.09 & 0.24 & 0.27 & 0.015 & 0.016 \\
\hline $\mathrm{Mo}^{2+}, \mathrm{mg} / \mathrm{dm}^{3}$ & 0.001 & 0.006 & 0.001 & 0.006 & 0.002 & 0.002 & 0.004 & 0.003 \\
\hline $\mathrm{Cu}^{2+}, \mathrm{mg} / \mathrm{dm}^{3}$ & 0.01 & 0.01 & 0.01 & 0.02 & 0.01 & 0.01 & 0.02 & 0.01 \\
\hline $\mathrm{Zn}^{2+}, \mathrm{mg} / \mathrm{dm}^{3}$ & 0.004 & 0.013 & 0.022 & 0.013 & 0.021 & 0.018 & 0.013 & 0.012 \\
\hline $\mathrm{Pb}^{2+}, \mathrm{mg} / \mathrm{dm}^{3}$ & 0.012 & 0.009 & 0.002 & 0.002 & 0.003 & 0.007 & 0.006 & 0.006 \\
\hline phenols, $\mathrm{mg} / \mathrm{dm}^{3}$ & 0.001 & 0.0009 & 0.0005 & 0.0016 & 0.0021 & 0.001 & 0.0020 & 0.035 \\
\hline
\end{tabular}

Hazard quotients (HQ) of the substances contained in drinking water from the Bratsk public drinking water supply system for the adult population was found not to exceed the permissible level (1). For children, high level of hazard quotients was observed for lead $(\mathrm{HQ}=1.095)$ at a water quality control point (Bratsk) (Table 2).

With the additive unidirectional effect of the substances that enter the human body with drinking water, the hazard index for the adult population is estimated as negligible $(\mathrm{HI}=$ $0.43-0.48$ ) at water quality control points (Fig. 2).

Table 2. Hazard Quotient of Chemical Substances Contained in Drinking Water from the Bratsk Public Drinking Water Supply System.

\begin{tabular}{|c|c|c|c|c|c|c|c|c|c|c|}
\hline \multirow{2}{*}{$\begin{array}{l}\text { Water } \\
\text { quality } \\
\text { control } \\
\text { points }\end{array}$} & \multicolumn{8}{|c|}{ Hazard quotient of chemical substances } & \multirow{2}{*}{\multicolumn{2}{|c|}{$\begin{array}{l}\text { Average } \\
\text { values }\end{array}$}} \\
\hline & \multicolumn{2}{|c|}{ Bratsk (city) } & \multicolumn{2}{|c|}{ Zayarsk (village) } & \multicolumn{2}{|c|}{ Zayarsk (village) } & \multicolumn{2}{|c|}{ Zayarsk (village) } & & \\
\hline Substance & 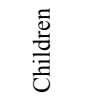 & $\frac{\frac{n}{3}}{\frac{3}{2}}$ & 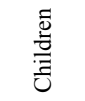 & $\frac{\stackrel{n}{E}}{\frac{7}{2}}$ & 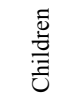 & $\frac{\mathscr{n}}{\vec{z}}$ & 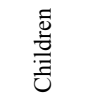 & 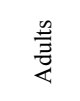 & 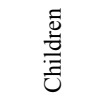 & $\frac{\stackrel{0}{E}}{\frac{3}{2}}$ \\
\hline 1 & 2 & 3 & 4 & 5 & 6 & 7 & 8 & 9 & 10 & 11 \\
\hline $\begin{array}{c}\mathrm{NO}_{3}^{-} \\
\mathrm{mg} / \mathrm{dm}^{3}\end{array}$ & 0.0922 & 0.0395 & 0.0208 & 0.0089 & 0.0393 & 0.0168 & 0.2351 & 0.1008 & 0.09685 & 0.04151 \\
\hline $\begin{array}{c}\mathrm{Fe}^{3+}, \\
\mathrm{mg} / \mathrm{dm}^{3}\end{array}$ & 0.0067 & 0.0029 & 0.0046 & 0.002 & 0.0107 & 0.0046 & 0.0067 & 0.0029 & 0.00718 & 0.00308 \\
\hline $\mathrm{F}^{-}, \mathrm{mg} / \mathrm{dm}^{3}$ & 0.554 & 0.2374 & 0.5601 & 0.2401 & 0.411 & 0.1761 & 0.4764 & 0.2042 & 0.50038 & 0.21445 \\
\hline $\begin{array}{l}\mathrm{Mn}^{2+}, \\
\mathrm{mg} / \mathrm{dm}^{3}\end{array}$ & 0.0012 & 0.0005 & 0.0032 & 0.0014 & 0.0008 & 0.0004 & 0.0003 & 0.0001 & 0.00137 & 0.00059 \\
\hline $\begin{array}{c}\mathrm{As}^{2+}, \\
\mathrm{mg} / \mathrm{dm}^{3}\end{array}$ & 0.0487 & 0.0209 & 0.1705 & 0.0731 & 0.1826 & 0.0783 & 0.0974 & 0.0417 & 0.12481 & 0.05349 \\
\hline $\mathrm{B}^{-}, \mathrm{mg} / \mathrm{dm}^{3}$ & 0.0852 & 0.0365 & 0.0493 & 0.0211 & 0.2314 & 0.0992 & 0.0805 & 0.0345 & 0.11160 & 0.04783 \\
\hline $\begin{array}{c}\mathrm{Mo}^{2+} \\
\mathrm{mg} / \mathrm{dm}^{3}\end{array}$ & 0.042 & 0.018 & 0.0393 & 0.0168 & 0.0438 & 0.0188 & 0.0402 & 0.0172 & 0.04132 & 0.01771 \\
\hline $\begin{array}{c}\mathrm{Cu}^{2+}, \\
\mathrm{mg} / \mathrm{dm}^{3}\end{array}$ & 0.0336 & 0.0144 & 0.0264 & 0.0113 & 0.0336 & 0.0144 & 0.0224 & 0.0096 & 0.02904 & 0.01245 \\
\hline $\begin{array}{c}\mathrm{Zn}^{2+}, \\
\mathrm{mg} / \mathrm{dm}^{3}\end{array}$ & 0.0032 & 0.0014 & 0.0041 & 0.0017 & 0.0037 & 0.0016 & 0.008 & 0.0034 & 0.00475 & 0.00204 \\
\hline $\begin{array}{c}\mathrm{Pb}^{2+}, \\
\mathrm{mg} / \mathrm{dm}^{3}\end{array}$ & 1.0959 & 0.4697 & 0.0462 & 0.0198 & 0.1035 & 0.0444 & 0.1644 & 0.0705 & 0.35249 & 0.15107 \\
\hline $\begin{array}{l}\text { phenols, } \\
\mathrm{mg} / \mathrm{dm}^{3}\end{array}$ & 0.0001 & 0 & 0.0002 & 0 & 0.0001 & 0 & 0.0002 & 0 & 0.00017 & 0.0 \\
\hline
\end{tabular}




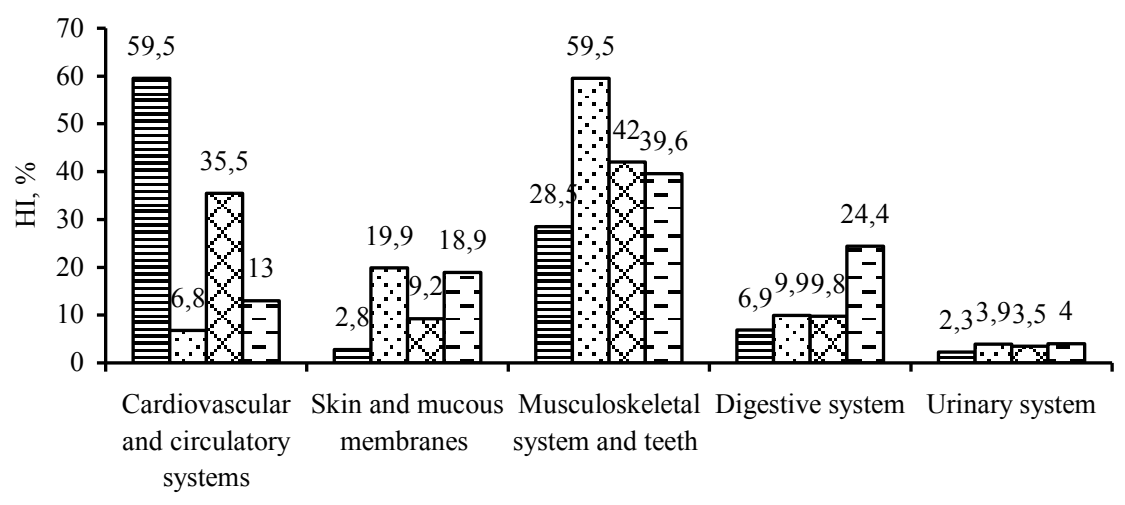

日Bratsk $\square$ Padun $\boldsymbol{Q}$ Zayarsk $\boldsymbol{\nabla}$ Bikey

Fig. 2. Hazard indices for critical systems of the human body exposed to drinking water from the Bratsk drinking water supply system.

Taking into account that toxic agents are tropic in relation to organs and systems of the human body, we found that the digestive system, circulatory and hematopoietic system, skin, mucous membranes, and the musculoskeletal system of children are under the greatest toxic load. There is an increased risk of bone tissue and teeth disorders in this group of Bikey village $(\mathrm{HI}=1.19)$, where fluorides are the major contributor. High hazard indices $(\mathrm{HI}=1.19)$ are caused by nitrates contained in drinking water in concentrations exceeding the MAC in $27.9 \%$ of samples, and by fluorides $(\mathrm{HI}=1.19)$ contained in drinking water in concentrations exceeding the MPC in $24.6 \%$ of samples in Zayarsk village.

As compared to adults, children have more organs and systems affected by polluted drinking water. For example, in relation to drinking water from pumping stations of the Bratsk public drinking water supply system, hazard indices for the cardiovascular and circulatory systems were found to exceed the permissible level $(\mathrm{HI}=1.19)$. Among the tested chemical substances contained in drinking water, nitrates and fluorine (in terms of non-carcinogenic (general toxic) effects) and lead (in terms of carcinogenic effects) have the highest levels of hazard to public health in the Irkutsk Region, including Bratsk.

Thus, the public health risk of drinking water directly depends on a water treatment technique, its compliance with a water source category and the sanitary condition of the city's distribution networks. In order to provide the population of urban districts and municipal areas of Bratsk with high-quality drinking water, it is necessary to implement a variety of measures, as well as to develop and implement programs aimed at improving water supply to settlements.

\section{Conclusion}

The public health risk assessment shows that the toxicological hazard of drinking water from the public drinking water supply system in certain areas of the Irkutsk Region is acceptable for adults, but exceeds the permissible level for children and is associated with exposure to lead.

Long-term quality monitoring of raw water in water sources and drinking water from public water supply systems, as well as calculated quantitative and qualitative characteristics of the public health risk associated with water consumption, are important information sources for introducing the risk-based model of surveillance in the field of 
sanitary and epidemiological public welfare. Depending on hazard level of activities of business entities, characteristics of the public health risk are an additional criterion for selecting priority projects at the planning stage. Subject to the estimated risk levels and in the context of the exposure to the water factor that can lead to adverse effects on critical organs and systems of the human body, it is necessary to develop a set of measures for managing the public health risk.

\section{References}

1. L.K. Kazanceva, T.O. Tagaeva, ECO 9, 30-37 (2006)

2. R. Shehzadi, H.M. Rafique, I. Abbas, M.A. Sohl, Sh.M. Ramay, A. Mahmood, Desalination and Water Treatment 55 (8), 2253-2264 (2015)

3. L.E.A. Bradford, L.A. Bharadwaj, U. Okpalauwaekwe, Ch.L, Waldner, International Journal of Circumpolar Health 75(1) (2016)

4. L. Benneyworth, J. Gilligan, J.C. Ayers, S. Goodbred, G. George, A. Carrico, International Journal of Environmental Health Research 26 (5-6), 508-524 (2016)

5. V.A. Vasilenko, ECO 2, 128-142 (2006)

6. N.V. Efimova, N.I. Matorova, N.N. Jushkov, V.A. Nikiforova, T.G. Perceva, Medikojekologicheskie riski sovremennogo goroda [Medical and ecological risks of the modern city], 200 (BrSU, Bratsk, 2008)

7. L.G. Konshina, M.V. Sergeeva, L.L. Lipanova, A.V. Solonin, Hygiene and sanitation 2, 22-24 (2004)

8. R.G. Taylor, K.W.F. Howard, Groundwater quality in rural Uganda: hydrochemical consideration for the development of aquifers within basement complex of Africa, In: Nash H., McCall G.J.H., eds. Groundwater Quality, 31-44 (Chapman and Hall, London, 1994)

9. N. Sohel, L.A. Persson, M. Rahman, P.K. Streatfield, M. Yunus, E.C. Ekström, M. Vahter, Epidemiology 20(6), 824-830 (2009)

10. G.G. Onishchenko, Health Care of the Russian Federation 4, 3-9 (2007)

11. N.V. Zaytceva, I.V. Mai, S.Yu. Balashov, Izvestia of Samara Scientific Center of the Russian Academy of Sciences 1-6 (1), 1144-1148 (2009)

12. S. Rapant, K. Kremova, Environ. Geochem. Health 29, 131-141 (2007)

13. A.V. Zagaynova, Yu.A. Rahmanin, Yu.G. Talaeva et al., Hygiene and sanitation 3, 28-31 (2010)

14. A.A. Sekunda, L.P. Ignat'eva, O.A. Projdakova, L.A. Nikolaeva, Materials of the Plenum of the Scientific Council on Human Ecology and Environmental Hygiene of the Russian Academy of Medical Sciences: Methodical issues of studying the assessment and regulation of physical factors in environmental health, 71-72 (2008)

15. L.G. Konshina, V.L. Lezhnin, Hygiene and sanitation 3, 5-10, (2014)

16. D.V. Goryaev, I.V. Tikhonova, N.N. Torotenkova, Health Risk Analysis 3, 35-43, (2016)

17. A.E. Oparin, Sibirskij medicinskij zhurnal [Siberian Medical Journal] 5, 99-102, (2012)

18. G.G. Onishchenko, N.V. Zaytceva, Analiz riska zdorov'ju v strategii gosudarstvennogo social'no-jekonomicheskogo razvitija [Analysis of the health risk in the strategy of state social and economic development], 738(Perm national research polytechnic university, Perm, 2014)

19. G.I. Rumyantcev, Health Risk Analysis 2, 4-11 (2015)

20. SANPIN 2.1.4.1074-01. Potable Water - Hygienic Requirements for Water Quality in Central Potable Water Supply Systems - Quality Control, 84 (Ministry of Health of Russian Federation, Moscow, 2002) 
21. GN 2.2.5.1315-03. Maximum allowable concentrations (MACs) of chemicals in the water of water objects used for drinking and domestic-recreation purposes, 100 (Ministry of Health of Russian Federation, Moscow, 2003)

22. P 2.1.10.1920-04. Human Health Risk Assessment from Environmental Chemicals, 143 (Federal Center for State Sanitary and Epidemiological Supervision of the Ministry of Health of the Russian Federation, Moscow, 2004) 